\title{
The effect of sub-irrigation with untreated and treated municipal wastewater on organic matter and nitrogen content in two different soils
}

\author{
Tsigoida A. ${ }^{*}$ and Argyrokastritis I. \\ Department of Natural Resources Management \& Agricultural Engineering, School of Agricultural Production, Infrastructure and \\ Environment, Agricultural University of Athens, lera Odos 75, 11855, Athens, Greece \\ Received: 28/06/2018, Accepted: 30/07/2019, Available online: 09/09/2019 \\ *to whom all correspondence should be addressed: e-mail: tsigoida@aua.gr \\ https://doi.org/10.30955/gnj.002810
}

\begin{abstract}
The aim of this study is to investigate the effect of sub-irrigation with untreated and treated municipal wastewater on soil organic matter \% and nitrogen \%. Three treatments were used: untreated wastewater $U$, treated wastewater $T$ and tap water $W$ being the control treatment, in two soil types, Sandy loam SL and Loamy sand LS. A sub-irrigation system including pots filled with soil installed in one of the greenhouses of the Agricultural University of Athens. The wastewater used was applied in the soil in pots at a depth of $10 \mathrm{~cm}$ and $20 \mathrm{~cm}$. In order to determine the changes of organic matter \% and total $\mathrm{N} \%$ at the point where the emitter was placed, the soil was divided into two zones according to depth: (zone I -upper) and (zone Il-lower). The total $\mathrm{N} \%$, ammonia nitrogen $\left(\mathrm{NH}_{4}-\mathrm{N}\right)$, nitrogen nitrates $\left(\mathrm{NO}_{3}-\mathrm{N}\right)$ and organic matter \% were determined in the soil samples. Statistically significant differences $(p<0.05)$ were observed in organic matter \% and total $\mathrm{N} \%$ only for LS soil. Between the two zones, sub-irrigation with $\mathrm{T}$ at $\mathrm{a}$ depth of $20 \mathrm{~cm}$ resulted in an increase in organic matter \% in zone (I) for SL soil while for LS soil sub-irrigation with $U$ at a depth of $20 \mathrm{~cm}$ led to an increase of total $\mathrm{N} \%$ in zone (I) and nitrate and ammonium in zone (II) both statistically significant $(p<0.05)$.
\end{abstract}

Keywords: Wastewater, sub-irrigation, soil, organic matter, nitrogen content.

\section{Introduction}

As it was reported by WHO (World Health Organization) and UNESCO in their yearly report, by 2050 the world water demand will have increased to $20-30 \%$ in relation to today's needs (SLpress, 2019). Globally, 2.1 billion people lack safe water at home. (WHO, 2018). The EU Framework Directive for water encourages and promotes treated wastewater use in agriculture in order to overcome the problem of water scarcity. The urban wastewater implementation through sub-irrigation (Forslund et al., 2010) could potentially minimize risks to public health, especially for farm workers and consumers of the products of irrigated crops. Wastewater sub-irrigation use is considered the best technique to substitute natural water resources and to offer higher returns on crops (Duhrkoop et al., 2014). According to microbiological data given by researchers (Kiziloglu, 2008) for a more sustainable agriculture, untreated wastewater could be used for irrigation but for a short time while treated wastewater could be used for a longer term. Especially in agricultural areas where groundwater has been contaminated, the wastewater application could have a positive effect on soil quality (e.g. organic matter) under right conditions (Hidri et al., 2013).There have been expressed different opinions on the impact of wastewater on soil properties, which may be related to changes in physical, chemical or biological soil properties. In two different soil types, properties were showed important differences as far as conversion of nutrients are concerned, after wastewater application (Magesan et al., 1999). According to Galavi et al. (2010) and Wagner et al. (2006) in all soil parameters (N, P, K, Ca, Na, Mg, SAR, EC, OC \%) a significant increase ( $\mathrm{p} \leq 0.05)$ was observed after wastewater irrigation. Organic matter increased only to the top layer, depending on irrigation quantity. This effect can be explained either by directly adding nutrients and organic compounds to the soil or indirectly by enhancing the solubility of soil nutrients. According to Hidri et al. (2013), pH, organic matter and cation exchange capacity were not affected after drip irrigation with treated wastewater. Long-term irrigation with wastewater may create an increase in nutrients to soil (e.g. organic matter, nitrogen (N), salinity, heavy metals and the major of cations concentration), but may create a $\mathrm{pH}$ reduction, (Angin et al., 2005). Irrigation with treated wastewater after 4 years caused a $\mathrm{pH}$ decrease but a significant increase in organic matter OM, sodium absorption SAR and electrical conductivity EC was observed (Bedbabis et al., 2014.) Organic matter \%, total carbon TC \% and total $\mathrm{N} \%$ increased in the surface layer (up to $10 \mathrm{~cm}$ ) (Jian Xua, 2010). Moreover, after 80 years of irrigation with 
wastewater, total carbon TOC \% increased 2.5 fold. However, the microbial biomass activity increased, due to larger amounts of organic matter, while microorganism species changed and denitrification capacity increased (Friedel, 2000). The present paper attempts to determine the organic matter and nitrogen content in soil and the differences between two different soils after irrigation with untreated and treated wastewater. Also, it attempts to determine their changes in soil at the point of the sub-irrigation depth.

\section{Materials and methods}

\subsection{Experimental description}

Experiments were performed in one of the greenhouses of the Agricultural University of Athens. A specific watering system was installed. This system was used for the subsurface application of wastewater into the soil. The soil was packed into pots and sub-irrigation was applied in depths of 10 and $20 \mathrm{~cm}$. Two different soil types were used: SL soil characterized as Sandy Loam and LS soil characterized as Loamy Sand. Three treatments were applied: untreated wastewater $U$, treated wastewater $T$ and tap water $W$ as the control treatment. The wastewater was taken from the biological Wastewater Treatment Plant of Likovrisis in Attica (KEREFYT). At the end of the experimental procedure, soil samples were taken to the laboratory in order to determine their chemical properties. The soil of each pot was divided into two zones defined by the level where the emitter was placed. They were labeled as the upper (I) and the lower (II) zone. Soil samples were taken in order to determine the changes of Nitrogen and organic matter concentrations in the soil. The following parameters were determined: The total $\mathrm{N} \%$, the ammonia nitrogen $\left(\mathrm{NH}_{4}-\mathrm{N}\right)$, the nitrate nitrogen $\left(\mathrm{NO}_{3}-\mathrm{N}\right)$ and the organic matter \%.

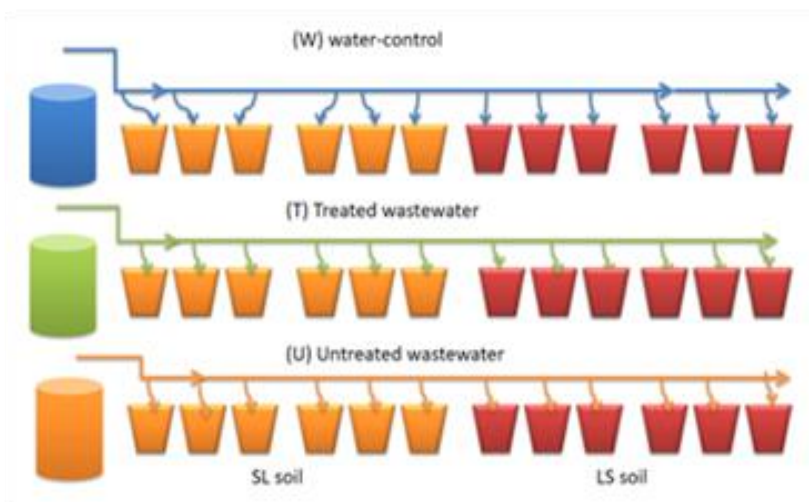

Figure 1. The layout of the pots

\subsection{Experimental design}

For the needs of the experiment, 36 pots were used (Figure 1). The capacity of each pot was 11.8 liters and it was filled with $13 \mathrm{~kg}$ of soil. Soil was homogenized, passed through a sieve (having a mesh of $1.0 \times 1.0 \mathrm{~cm}$ ) and was dried in the air (Chen et al., 2000). Then the soil was weighed and was placed into the pots. Each pot contained $13 \mathrm{~kg}$ of soil and care was taken in order to ensure equal quantity in all pots. A subsurface drip irrigation system (SDIS) with single drippers was installed for wastewater and/or water application to be used into the pots. The experimental layout consisted of three rows of pots. In the first row tap water $W$ was applied while in the second and the third one treated $T$ and untreated wastewater $U$ was applied respectively. The tap water treatment was taken as the control treatment. Each row consisted of 12 pots and three repetitions for each treatment were used. In each pot the above liquids were applied in order to bring the soil at pot capacity $\left(\Theta_{F C}\right)$ of about $70-75 \%$ of the saturated water content. A flow rate of $3 \mathrm{l} / \mathrm{h}$ irrigation was applied (Allen et al., 1998). So, each dripper provided $3 \mathrm{l} / \mathrm{h}$ of wastewater and/or tap water and the available soil moisture content did not exceed the value of $70-75 \%$ of the saturated water content. The system was programmed to operate for one hour, three days a week. For the wastewater application, plastic pipes (diameter $32 \mathrm{~mm}$ ) and spaghetti type ones (diameter $6 \mathrm{~mm}$ ) were used. Emitters were connected to spaghetti tubes applying wastewater at $10 \mathrm{~cm}$ and $20 \mathrm{~cm}$ below the soil surface. A very fine sieve was used in order not to clog the drippers in the case of untreated wastewater. The treated wastewater used was in accordance to Greek guidelines (Andreadakis et al., 2003). The LS soil consisted of SL soil mixed with sand at a percentage of $25 \%$ in order to make it more permeable to wetting liquids. From the 36 pots used, 18 were filled with SL soil and the other 18 were filled with LS soil. Three rows of pots were established and each row consisted of 6 pots with SL soil and the other 6 with LS soil. In three of them the emitter was placed at a depth of $10 \mathrm{~cm}$ and in the other three ones the emitter was placed at a depth of $20 \mathrm{~cm}$. During the days that irrigation was applied, wastewater was taken in containers at the Agricultural University of Athens. The experiment lasted for six months.

\subsection{Soil sampling}

At the end of the experimental procedure, soil was removed from each pot so that the shape of the pot is kept. Then, based on the depth (10 and/or $20 \mathrm{~cm})$ at which the emitters were placed, the soil was divided into two parts (zones) and samples were taken from each part (Figure 2). The upper part was characterized as zone (I) and the bottom one as zone (II). Soil samples of the two zones were obtained in order to study the variation of soil nitrogen and organic matter percentage in two zones, compared to the control treatment after wastewater addition. Then the samples were taken to the laboratory for soil analysis and the following parameters were determined: Total $\mathrm{N} \%$ and organic matter \% and ammonia nitrogen $\left(\mathrm{NH}_{4}-\mathrm{N}\right)$, and nitrogen nitrate $\left(\mathrm{NO}_{3}-\mathrm{N}\right)$. 


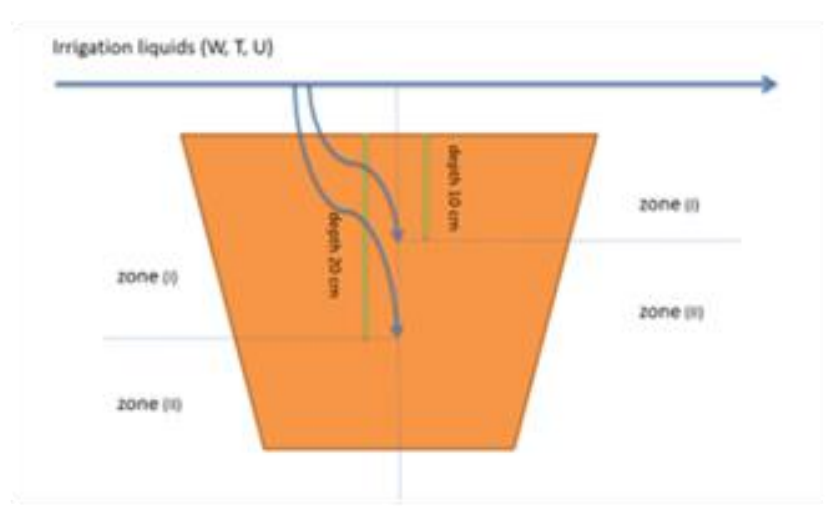

Figure 2. The section of the pot (depths 10, $20 \mathrm{~cm}$ )

\subsection{Soil chemical analysis}

Soil samples were air dried and then passed through a sieve of $2 \mathrm{~mm}$ openings. In the soil fraction of particle size $<2 \mathrm{~mm}$, the above mentioned parameters were determined by using the following methods: The soil texture of the soil samples was determined by using the Bouyoukos method (Bouyoukos, 1951). The organic matter percentage of the soil samples in wet oxidation of the sample was determined by using the Wakley-Black method (Nelson and Sommers, 1982). The total N \% of the soil samples was determined by using the Kjieldahl method (Bremmer and Mulvaney, 1982). The ammonia nitrogen $\left(\mathrm{NH}_{4}-\mathrm{N}\right)$ of the soil samples was determined by using the indophenol method (indophenol blue method), while the nitrate nitrogen $\left(\mathrm{NO}_{3}-\mathrm{N}\right)$ was determined by using the cadmium method.

\subsection{Statistical analysis}

To assess the differences in the chemical parameters of the soil, the analysis of variance (ANOVA) was used. All statistical analyses were performed at a significance level of $p \leq 0.05$. When significant effects were determined ( $p \leq 0.05$ ) during multiple comparisons, the Tukey's test was applied in order to find means that are significantly different from each other. The statistical software package SIGMA STAT was used for all statistical determinations.

\subsection{The hydraulic conductivity of the soils used}

In soil samples taken from the SL and LS soils used in the experiments the saturated hydraulic conductivity (Ks), the saturated volumetric water content $(\Theta s)$ and the soil bulk density $\left(\rho_{b}\right)$ were determined and their values are shown as follows:

Soil a (SL): Ks $(\mathrm{cm} / \mathrm{h})=89.95$, Os $\left(\mathrm{m}^{3} / \mathrm{m}^{3}\right)=0.374$, $\rho_{b}$ $\left(\mathrm{t} / \mathrm{m}^{3}\right)=1.2$. Soil b $(\mathrm{LS})$ : Ks $(\mathrm{cm} / \mathrm{h})=63.19$, Os $\left(\mathrm{m}^{3} / \mathrm{m}^{3}\right)=$ 0355, $\rho_{b}\left(t / \mathrm{m}^{3}\right)=1.25$

\section{Results and Discussion}

\subsection{Characteristics of the wastewater}

Generally, the untreated wastewater reuse for irrigation is not suggested because dangerous bacteria and compounds are transferred in soil. While according to WHO and EE there are strict guidelines for treated wastewater irrigation, which were adapted by some nations. In this paper an attempt was made to investigate if the untreated wastewater examined by the sub-irrigation method could provide some reuse solutions in particular cases. Table 1 shows the mean values of the chemical parameters found in the wastewater used before irrigation was applied. As it was expected, the untreated wastewater contains high percentages of SS $(\mathrm{mg} / \mathrm{l})$ and COD $(\mathrm{mg} / \mathrm{l})$.

Table 1. The wastewater chemical parameters

\begin{tabular}{cccc}
\hline Parameters & U Untreated & T Treated & W Water \\
\hline $\mathrm{pH}$ & 7.52 & 7.24 & - \\
\hline $\mathrm{COD}(\mathrm{mg} / \mathrm{l})$ & $560-988$ & $17.9-23.5$ & - \\
\hline $\mathrm{SS}(\mathrm{mg} / \mathrm{l})$ & 235.4 & 0.71 & - \\
\hline $\mathrm{NO}_{3}{ }^{-} \mathrm{N}(\mu \mathrm{g} / \mathrm{ml})$ & 0.35 & 1.48 & - \\
\hline $\mathrm{NH}_{4}{ }^{+}-\mathrm{N}(\mu \mathrm{g} / \mathrm{ml})$ & 21.81 & 0.068 & - \\
\hline total P $(\mu \mathrm{g} / \mathrm{ml})$ & 4.41 & 4.08 & - \\
\hline $\mathrm{K}^{+}(\mu \mathrm{g} / \mathrm{ml})$ & 20 & 22 & - \\
\hline $\mathrm{Na}^{+}(\mu \mathrm{g} / \mathrm{ml})$ & 92 & 95 & 70.3 \\
\hline $\mathrm{Cl}^{-}(\mathrm{meq} / \mathrm{l})$ & 0.7 & 0.6 & 1.3 \\
\hline $\mathrm{EC}(\mu \mathrm{S} / \mathrm{cm})$ & 1090 & 814 & 920 \\
\hline $\mathrm{T} \mathrm{H}(\mathrm{meq} / \mathrm{l})$ & 4.3 & 4.1 & 6.75 \\
\hline $\mathrm{SAR}$ & 2.73 & 2.88 & 1.66 \\
\hline
\end{tabular}

3.2. The chemical parameters determined for $S L$ and $L S$ soils

In Table 2, the parameters measured in SL and LS soils at the end of irrigation period are presented. Initially there not seem to be big differences in the parameters; however, after the statistical analyses the results seem to show some significant differences, especially for LS soil.

Table 2. the average results and the standard deviation of the parameters measured in SL and LS soils by chemical analysis at the end of irrigation period with $U$ untreated, $T$ treated wastewater and $W$ water

\begin{tabular}{|c|c|c|c|c|c|c|c|c|c|c|}
\hline \multirow{2}{*}{ Treatments } & \multirow{2}{*}{ Soil } & \multirow{2}{*}{ No samples- } & \multicolumn{2}{|c|}{ Organic matter \% } & \multicolumn{2}{|c|}{ Total N \% } & \multicolumn{2}{|c|}{$\mathrm{NO}_{3}-\mathrm{N} \mu \mathrm{g} / \mathrm{g}$} & \multicolumn{2}{|c|}{$\mathrm{NH}_{4}{ }^{+}-\mathrm{N} \mu \mathrm{g} / \mathrm{g}$} \\
\hline & & & avg & Sd & avg & Sd & avg & Sd & avg & Sd \\
\hline \multirow{2}{*}{ U Untreated } & SL & 72 & 032 & 0.07 & 0.117 & 0.01 & 4.88 & 1.94 & 1.74 & 0.47 \\
\hline & LS & 72 & 0.36 & 0.04 & 0.121 & 0.00 & 4.18 & 1.58 & 1.67 & 0.31 \\
\hline \multirow{2}{*}{ T Treated } & SL & 72 & 0.37 & 0.10 & 0.110 & 0.01 & 4.04 & 1.61 & 1.73 & 0.54 \\
\hline & LS & 72 & 0.31 & 0.05 & 0.112 & 0.00 & 5.04 & 1.29 & 1.66 & 0.37 \\
\hline \multirow{2}{*}{ W control } & $\mathrm{SL}$ & 72 & 0.32 & 0.07 & 0.108 & 0.03 & 3.71 & 1.66 & 1.58 & 0.41 \\
\hline & LS & 72 & 0.24 & 0.03 & 0.110 & 0.00 & 4.12 & 2.00 & 1.17 & 0.53 \\
\hline
\end{tabular}


Figure 3 shows the differences between SL and LS soils at the end of the irrigation period. The tables below show the examined chemical parameters after statistical analysis by ANOVA and t-test. In Table 3, organic matter \% and total $\mathrm{N} \%$ show significant differences ( $p<0.05$ ) between SI and LS soils. In Table 4, organic matter \%, total $\mathrm{N} \%$ and $\mathrm{NH}_{4}{ }^{+}-\mathrm{N} \mu \mathrm{g} / \mathrm{g}$ show significant differences ( $\mathrm{p}<$ $0.05)$ among three treatments, only for LS soil. Also in Table 5, organic matter \%, total $\mathrm{N} \%$ and $\mathrm{NH}_{4}{ }^{+}-\mathrm{N} \mu \mathrm{g} / \mathrm{g}$ show significant differences $(p<0.05)$ when treatments were compared between them for every soil. That fact shows that LS soil is more affected than SL soil by $U$ and $T$ treatments, especially by $U$ treatment. In Tables 6 and 7, the comparison (statistical analysis by using ANOVA) between SL and LS soils is presented. In Table 6, only organic matter $\%$ was significantly different $(p<0.05)$ between the two soils. In Table 7, the two soils were compared for the same treatment and organic matter \% was showed significant differences in $\mathrm{T}$ and $\mathrm{W}$ treatments.
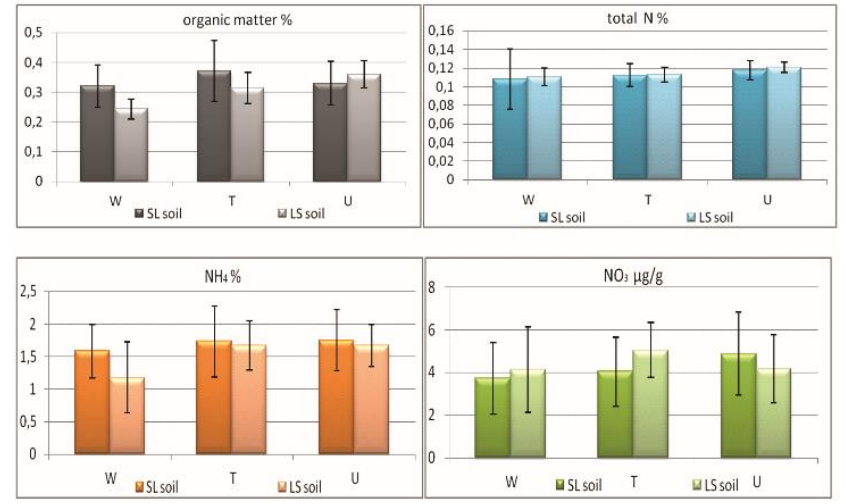

Figure 3. Differences in a) organic matter $\%$, b) b) total $\mathrm{N}$ $\%$, c) $\mathrm{NO}_{3}{ }^{-} \mathrm{mg} / \mathrm{g}$ and d) $\mathrm{NH}_{4}{ }^{+} \mathrm{mg} / \mathrm{g}$ of $\mathrm{SL}$ and $\mathrm{LS}$ soils, at the end the of irrigation period with three wetting liquids (W, $T, U)$. The vertical bars represent the standard deviation of the mean values $(n=3)$

Table 3. One way analysis of variance (ANOVA) in each chemical parameter for SL and LS soils

\begin{tabular}{ccccccc}
\hline \multirow{2}{*}{ Parameters } & \multicolumn{2}{c}{ SL soil } & \multicolumn{2}{c}{ LS soil } & & \multirow{2}{*}{ Test: One way analysis of variance (ANOVA) $\mathbf{p}<0.05$} \\
\cline { 2 - 4 } & avg & Sd & avg & Sd & & Normality failed, $\mathrm{K}-\mathrm{W}$ analysis $p=0.001$ (statistically significant) \\
\hline Organic matter \% & 0.32 & 0.07 & 0.24 & 0.03 & & Normality failed, $\mathrm{K}-\mathrm{W}$ analysis $\mathrm{p}=0.045$ (statistically significant) \\
\hline Total $\mathrm{N} \%$ & 0.108 & 0.03 & 0.11 & 0.00 & & $\mathrm{p}=0.802$ \\
\hline $\mathrm{NO}_{3}-\mathrm{N} \mu \mathrm{g} / \mathrm{g}$ & 3.71 & 1.66 & 4.12 & 2.00 & Normality failed, $\mathrm{K}-\mathrm{W}$ analysis $\mathrm{p}=0.149$ \\
\hline $\mathrm{NH}_{4}{ }^{+}-\mathrm{N} \mu \mathrm{g} / \mathrm{g}$ & 1.58 & 0.41 & 1.17 & 0.53 &
\end{tabular}

Note: $K$-W analysis $=$ Kruskal-Wallis one way analysis on ranks (Tukey)

Table 4. One way Analysis of Variance (ANOVA) among three treatments (W, T, and U) for each chemical parameter for SL and LS soils

\begin{tabular}{|c|c|c|c|}
\hline \multirow{2}{*}{ Parameters } & & \multicolumn{2}{|c|}{ One way Analysis of Variance-ANOVA (U vs T vs W) $p<0.05$} \\
\hline & & SL soil & LS soil \\
\hline Organic matter \% & W-T-U & $p=0.365$ & $\begin{array}{c}\text { (normality failed) Tukey test } p \leq 0.001 \text { Dunn's method } p \leq 0.001 \\
\text { (statistically significant) }\end{array}$ \\
\hline Total N \% & W-T-U & $\begin{array}{l}\text { (normality failed) K-W } \\
\text { analysis } p=0.499\end{array}$ & $\begin{array}{c}\text { (normality failed) Tukey test } \mathrm{p}=0.004, \mathrm{~K}-\mathrm{W} \text { analysis } \mathrm{p}=0.002 \\
\text { (statistically significant) }\end{array}$ \\
\hline $\mathrm{NO}_{3}-\mathrm{N} \mu \mathrm{g} / \mathrm{g}$ & W-T-U & $p=0.234$ & $p=0.629$ \\
\hline $\mathrm{NH}_{4}{ }^{+}-\mathrm{N} \mu \mathrm{g} / \mathrm{g}$ & W-T-U & $p=0.664$ & Normality passed, Tukey test $p=0.009$ (statistically significant) \\
\hline
\end{tabular}

Note: $K-W$ analysis = Kruskal-Wallis one way analysis on ranks

\subsubsection{Organic matter}

After six months of irrigation with treated $\mathrm{T}$ and untreated $\mathrm{U}$ wastewater on SL and LS soils an increase in organic matter \%, compared to the control treatment (W) was observed. The increase is greater in SL soil (in treatment T) but not statistically significant ( $p=0.365$ ). In LS soil, the increase is greater in treatment with $U$ statistically significant ( $\leq 0.001$ ) (see Table 4). When the treatment $U$ was compared to $W$ and $T$ treatments, in SL soil the differences were not statistically significant. In LS soil there were statistically significant differences (t-test $\mathrm{p}<0.05$ ) when $U$ treatment was compared with control and treated one ( $U$ vs $W$ and $U$ vs T) (see Table 5). Between SL and LS soils, organic matter \% was statistically significant ( $p<0.033$ ) (see Table 6). Between the same treatments for the two soils, statistically significant differences were observed for organic matter \% (see Table 7). Zhang et al. (2008), Abegunrin (2016), and Qian and Mecham (2005) have reported a significant increase in organic matter \% which showed that the soil structure was improved. Rusan et al. (2007) and Hidri et al. (2013) have reported positive effects on soil after irrigation with treated wastewater. Also, Mohammad et al. (2007) have reported that soil organic matter \% increased significantly $(p<0.05)$ after irrigation with wastewater. After four years of irrigation with wastewater a significant increase in organic matter has been reported by Bedbabis et al. (2014), Ghanbari et al. (2007), Mohammad and Mazahreh (2003), and Monnett et al. (1996) and that also showed improved soil structure. Additionally, organic matter increased as the irrigation was increased with benefits to the soil (Wang et al., 2007; Walker and lin, 2007; Rusan et al., 2007). According to Galavi et al. (2010) organic carbon $(O C) \%$ increased significantly $(p \leq 0.05)$ and total 
carbon (TC) increased up to 7\% (Alrajhi, 2015; Jiajie, 2013) after wastewater irrigation. Also, Abegunrin (2016) found that wastewater irrigation caused an increase of hydrophobicity in subsoil. According to the experimental data obtained by the researchers (Kalavrouziotis I. et al.,
2018), it was shown that there is a statistically significant relationship between the pollution indices and the soil factors $\mathrm{pH}$ and organic matter.

Table 5. t-test analysis between each other treatments for each chemical parameter for SL soil and for LS soil

\begin{tabular}{|c|c|c|c|c|c|c|}
\hline \multicolumn{7}{|c|}{ Test: t-test $p<0.05$} \\
\hline \multirow{2}{*}{ Parameters } & \multicolumn{3}{|c|}{ SL soil } & \multicolumn{3}{|c|}{ LS soil } \\
\hline & U vs W & T vs W & T vs U & U vs W & T vs W & T vs U \\
\hline Organic matter \% & $\begin{array}{l}M-W \text { test } \\
p=0.769\end{array}$ & $p=0.239$ & $p=0.265$ & $\begin{array}{c}\text { M-W test } p<0.001 \\
\text { (statistically significant) }\end{array}$ & $\begin{array}{l}M-W \text { test } \\
p=0.976\end{array}$ & $\begin{array}{c}M-W \text { test } p<0.001 \\
\text { (statistically significant) }\end{array}$ \\
\hline Total N \% & $\begin{array}{l}M-W \text { test } \\
p=0.977\end{array}$ & $\begin{array}{l}M-W \text { test } \\
p=0.235\end{array}$ & $p=0.425$ & $\begin{array}{c}\mathrm{p}<0.004 \text { (statistically } \\
\text { significant) }\end{array}$ & $\begin{array}{l}M-W \text { test } \\
p=0.771\end{array}$ & $\begin{array}{c}\mathrm{p}<0.002 \text { (statistically } \\
\text { significant) }\end{array}$ \\
\hline $\mathrm{NO}_{3}{ }^{-}-\mathrm{N} \mu \mathrm{g} / \mathrm{g}$ & $p=0.120$ & $p=0.619$ & $p=0.248$ & $p=0.501$ & $p=0.381$ & $p=0.863$ \\
\hline $\mathrm{NH}_{4}{ }^{+}-\mathrm{N} \mu \mathrm{g} / \mathrm{g}$ & $p=0.381$ & $p=0.468$ & $p=0.926$ & $\begin{array}{c}\mathrm{p}<0.007 \text { (statistically } \\
\text { significant) }\end{array}$ & $p=0.105$ & $p=0.065$ \\
\hline
\end{tabular}

Note: $M-$ W test = Mann-Whitney Rank Sum test

\subsubsection{Total nitrogen}

Both SL and LS soils were showed an increase in both treatments $(T, U)$. The increase was greater for $L S$ soil, in $\mathrm{U}$ treatment compared to the control one $(\mathrm{W})(\mathrm{p} \leq 0.002)$ (see Table 4). Also, between two treatments (U vs W) ( $p<$ $0.004)$ and ( $T$ vs $U)(p<0.002)$ total $N \%$ was increased significantly for LS soil (see Table 5). When SL and LS soils were compared for the same treatment, total N\% was statistically significant only in control treatment $\left(W_{\alpha}\right.$ Vs $\left.W_{\beta}\right)(p \leq 0.032)$ (see Yable 7). Qian and Mecham (2005), Galavi et al. (2010), Bali et al. (2011), Abegunrin (2016), and Jiajie (2013) found that during irrigation with wastewater there was a significant increase in total $\mathrm{N} \%(\mathrm{p}$ $\leq 0.05$ ) and according to Alrajhi (2015) total N\% increased by $4 \%$. This could be explained by the fact that wastewater addition to soil increases nitrogen concentration (Monnett et al., 1996; Fuentes et al., 2002;
Cooper et al., 2015) which could be attributed to urea and nitrogen contained in the urban wastewater (Bernala et al., 2006; Fonseca et al., 2005a). Irrigation with treated wastewater resulted in retention of $50 \%$ of total $\mathrm{N} \%$ and the nitrogen available formats $\left(\mathrm{NO}_{3}\right.$ and $\left.\mathrm{NH}_{4}\right)$ which substantially increased by the quantity of irrigation. Ammonium and nitrates can be transferred either directly from wastewater or indirectly by organic matter conversion cycle and the subsequent mineralization of nitrogen (Belaid et al., 2012). Unlike Majed, (1999) it was observed that irrigation with treated wastewater did not affect significantly nitrogen content in soil. Also in another study, no significant effect on total $\mathrm{N} \%$ was observed after irrigation, because total $\mathrm{N} \%$ was maintained at the same level between wastewater inflow and outflow in soil columns (Lian, 2013).

Table 6. One way analysis of variance (ANOVA) between soils SL and LS

\begin{tabular}{cc}
\hline Parameters & Test: One way Analysis of Variance-ANOVA (SL soil Vs LS soil) \\
\hline Organic matter \% & Normality passed, Holm-Sidak method: $p<0.033$ (statistically significant) \\
\hline Total $\mathrm{N} \%$ & Normality failed, $\mathrm{p}=0.446$ \\
\hline $\mathrm{NO}_{3}-\mathrm{N} \mu \mathrm{g} / \mathrm{g}$ & Normality passed, $\mathrm{p}=0.427$ \\
\hline $\mathrm{NH}_{4}{ }^{+}-\mathrm{N} \mu \mathrm{g} / \mathrm{g}$ & Normality passed, $\mathrm{p}=0.116$ \\
\hline
\end{tabular}

\subsubsection{Nitrates}

Both SL and LS soils show an increase in both treatments $(T, \quad U)$ which is not statistically significant ( $p>0.05$ ) (see Table 4) and between treatments for SL and LS soils, nitrates did not differ (see Table 5). In comparison between the same treatment for soils SL and LS they did not differ also (see Table 7) .Also, Qian and Mecham (2005) observed an increase not statistically significant. According to Yadav et al. (2002) nitrates concentration contained in untreated wastewater are much lower than in treated one. According to Bali et al. (2011) and Jiajie (2013), an increase in $\mathrm{NO}_{3}-\mathrm{N}$ in filtered water was observed, when wastewater after secondary treatment was applied in an unsaturated sand layer. In addition, nitrates increased in full depth of the soil (sandy, clayey, limestone-clayey). According to Lado et al. (2012) this nitrates increase occurs in soil due to nitrification. Most nitrates are filtered in vadose zone in which they are subjected to biological attenuation up to groundwater. This fact demonstrates that below vadose zone denitrification does not occur and this is confirmed by $\mathrm{NO}_{3}{ }^{-}, \mathrm{SO}_{4}{ }^{2-}$ and $\mathrm{Cl}^{-}$salts (Zhang et al., 2013). The abundance of denitrifier agents is a valuable indicator that combines dynamic activity denitrification (potential denitrification activity) (PDA) and different environmental factors. Therefore, denitrification is a good indicator of the environmental changes in soil after irrigation with 
wastewater for about 25 years (Guo et al., 2013). Moreover, Magesan et al. (2000) have observed a reduction of nitrates by drainage in soils irrigated with treated wastewater. As it has been reported by Herpin et al. (2007) the effects on the cycle conversion of nutrient ingredients were mostly influenced by the $\mathrm{C} / \mathrm{N}$ ratio in soil and discharge of wastewater.

Table 7. One way analysis of variance (ANOVA) between the same treatment (W, T and U) for the soils SL and LS

\begin{tabular}{|c|c|c|}
\hline \multirow[t]{2}{*}{ Parameters } & \multicolumn{2}{|r|}{ Test: One way Analysis of Variance-ANOVA (SL soil Vs LS soil) } \\
\hline & $\mathrm{W}_{\mathrm{a}} \mathrm{Vs}_{\mathrm{s}} \mathrm{W}_{\mathrm{b}}$ & Norm. failed, Tukey, K-W analysis $p \leq 0.001$ (statistically significant) \\
\hline \multirow{2}{*}{ Organic matter \% } & $U_{a} V s U_{b}$ & Normality failed, $\mathrm{K}-\mathrm{W}$ analysis $\mathrm{p}=0.183$ \\
\hline & $W_{a} V_{s} W_{b}$ & Normality failed, Tukey, K-W analysis $p \leq 0.032$ (statistically significant) \\
\hline \multirow{2}{*}{ Total N \% } & $U_{a} V_{s} U_{b}$ & Normality passed, $p=0.206$ \\
\hline & $\mathrm{W}_{\mathrm{a}} \mathrm{Vs}_{\mathrm{s}} \mathrm{W}_{\mathrm{b}}$ & Normality passed, $\mathrm{p}=1.000$ \\
\hline \multirow[t]{3}{*}{$\mathrm{NO}_{3}-\mathrm{N} \mu \mathrm{g} / \mathrm{g}$} & $\mathrm{T}_{\mathrm{a}} \mathrm{Vs} \mathrm{T}_{\mathrm{b}}$ & Normality passed, $p=0.263$ \\
\hline & $\mathrm{U}_{\mathrm{a}} \mathrm{Vs}_{\mathrm{b}}$ & Normality passed, $p=0.705$ \\
\hline & $\mathrm{W}_{\mathrm{a}} \mathrm{Vs}_{\mathrm{s}} \mathrm{W}_{\mathrm{b}}$ & Normality passed, $\mathrm{p}=0.072$ \\
\hline $\mathrm{NH}_{4}^{+}-\mathrm{N} \mu \mathrm{g} / \mathrm{g}$ & $\mathrm{T}_{\mathrm{a}} \mathrm{Vs}_{\mathrm{s}} \mathrm{T}_{\mathrm{b}}$ & Normality passed, $p=0.247$ \\
\hline
\end{tabular}

Note: $K-W$ analysis $=$ Kruskal-Wallis one way analysis on ranks. $\left(W_{a}, W_{b}\right),\left(T_{a}, T_{b}\right),\left(U_{a}, U_{b}\right)$ : soils a and $b$ in three treatments $(W, T, U)$

\subsubsection{Ammonium}

Both treatments with wastewater $(T, U)$ in SL and LS soils showed an increase, which was statistically significant $p<0.009$ only in LS soil among three treatments (see Table 4). When SL soil and LS soil were compared for all treatments, the $U$ treatment was statistically significant $p<0.007$ versus the control one ( $U$ vs. $W$ ) for LS soil only (see Table 5). The comparison for the same treatment between SL and LS soils did not show differences (see Table 7). An ammonium increase was also observed by Qian and Mecham (2005) when soil was irrigated with wastewater. When urban wastewater was applied in columns of an unsaturated sand layer, $\mathrm{NH}_{4}-\mathrm{N}$ was showed a significant reduction, (Bali et al., 2011) and according to Nola et al. (2006) $\mathrm{NH}_{4}{ }^{+}$was withheld up from 97.37 to 98 , $74 \%$ in the soil profile. In clay soil $\mathrm{NH}_{4}-\mathrm{N}$ concentrations decreased after sub-irrigation with wastewater and this could be attributed to $\mathrm{NH}_{4}-\mathrm{N}$ nitrification and fixation within clay, and to $\mathrm{NH}_{3}$ volatilization (Jiajie, 2013). Theoretically, large ammonium quantities from wastewater may be removed when cation exchange capacity is sufficiently high during absorption in soil (Tyler et al., 1977; Lance, 1972). In Tables 3-5 the statistical analysis by using t-test for SL and LS soils are presented.

\subsection{The differences between zones (I, II) In SL and LS soils}

Figures 4 and 5 show the differences between zones (I) and (II) in SL and LS soil for 10 and $20 \mathrm{~cm}$, at the end of the irrigation period. Tables below ( 8 and 9) show the examined chemical parameters after statistical analysis by using t-test between zones (I, II) for SL and LS soils and for depths 10 and $20 \mathrm{~cm}$. In the depth of $10 \mathrm{~cm}, \mathrm{NO}_{3}^{-}-$ $\mathrm{N} \mu \mathrm{g} / \mathrm{g}$ was statistically significant $(\mathrm{p}<0.05)$ in $\mathrm{W}$ treatment for SL soil. In the depth of $20 \mathrm{~cm}$, organic matter \% in $\mathrm{T}$ treatment for SL soil and total $\mathrm{N} \%$ and $\mathrm{NH}_{4}{ }^{+}-\mathrm{N} \mu \mathrm{g} / \mathrm{g}$ in $\mathrm{U}$ treatment for LS soil were statistically significant $(p<0.05)$.

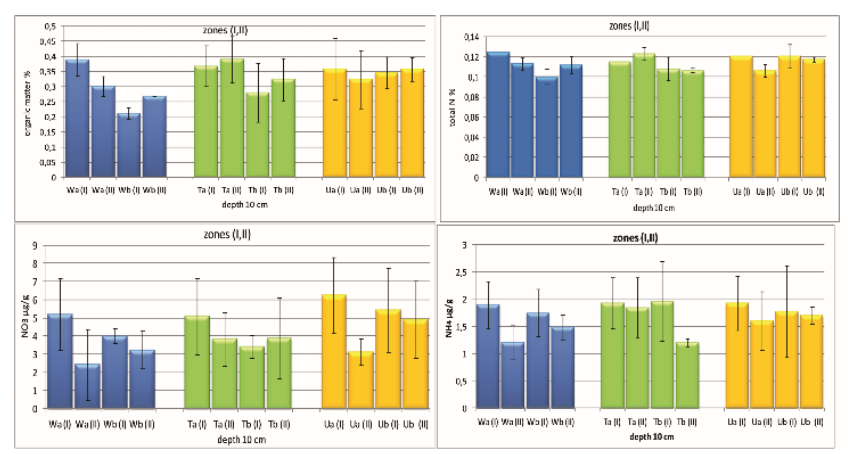

Figure 4. The variation of a) organic matter $\%, b$ ) total $\mathrm{N} \%, \mathrm{c}$ ) $\mathrm{NO}_{3} \mathrm{mg} / \mathrm{g}$ and d) $\mathrm{NH}_{4} \mathrm{mg} / \mathrm{g}$ in the two zones (I) and (II) at $10 \mathrm{~cm}$ depth of SL and LS soils at the end the of irrigation period with three wetting liquids $(\mathrm{W}, \mathrm{T}, \mathrm{U})$. The vertical bars represent the standard deviation of the mean values $(n=3)$

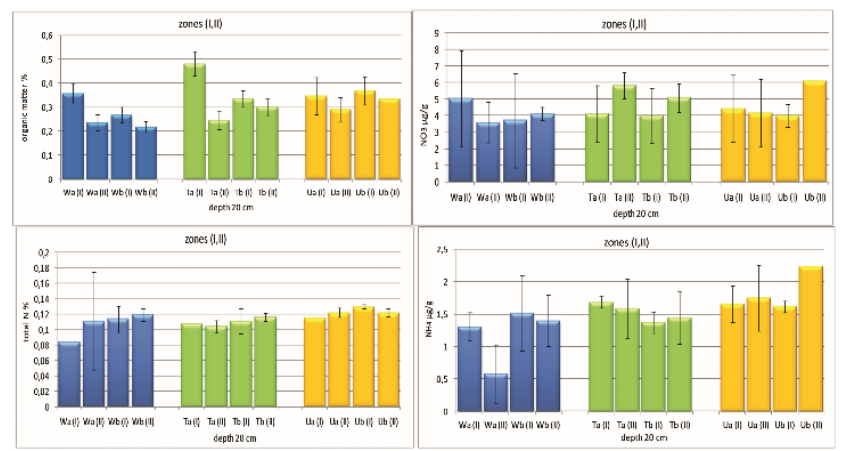

Figure 5. The variation of a) organic matter $\%, b)$ total $\mathrm{N}$ $\%$, c) $\mathrm{NO}_{3} \mathrm{mg} / \mathrm{g}$ and d) $\mathrm{NH}_{4} \mathrm{mg} / \mathrm{g}$ in the two zones (I) and (II) at $20 \mathrm{~cm}$ depth of SL and LS soils at the end the of irrigation period with three wetting liquids $(\mathrm{W}, \mathrm{T}, \mathrm{U})$. The vertical bars represent the standard deviation of the mean values $(n=3)$ 
Table 8. t-test analysis between zones (I) and (II) for SL and LS soils at $10 \mathrm{~cm}$ depth

\begin{tabular}{|c|c|c|c|}
\hline \multirow{2}{*}{ Parameters } & \multicolumn{3}{|c|}{ Test: t-test $p<0.05$} \\
\hline & Depth $10 \mathrm{~cm}$ & SL soil & LS soil \\
\hline \multirow{3}{*}{ Organic matter \% } & W (I)-(II) & 0.457 & 0.116 normality failed $M-W$ test $p=1.000$ \\
\hline & $\mathrm{T}(\mathrm{I})-(\mathrm{II})$ & 0.724 & 0.239 normality failed $M-W$ test $p=0.200$ \\
\hline & $U(I)-(I I)$ & 0.203 & 0.775 \\
\hline \multirow{3}{*}{ Total N \% } & W (I)-(II) & 0.482 & 0.280 \\
\hline & $\mathrm{T}(\mathrm{I})-(\mathrm{II})$ & 0.332 & 0.636 \\
\hline & $U(I)-(I I)$ & 0.139 & 0.482 \\
\hline \multirow{3}{*}{$\mathrm{NO}_{3}{ }^{-}-\mathrm{N} \mu \mathrm{g} / \mathrm{g}$} & W (I)-(II) & 0.017 (statistically significant) & 0.597 \\
\hline & $\mathrm{T}(\mathrm{I})-(\mathrm{II})$ & 0.447 & 0.189 \\
\hline & $U(I)-(I I)$ & $0.729 M-W$ test $p=0.700$ & 0.889 \\
\hline \multirow{3}{*}{$\mathrm{NH}_{4}{ }^{+}-\mathrm{N} \mu \mathrm{g} / \mathrm{g}$} & W (I)-(II) & 0.084 & 0.072 \\
\hline & $\mathrm{T}(\mathrm{I})-(\mathrm{II})$ & 0.852 & 0.730 \\
\hline & $U(I)-(I I)$ & 0.128 & 0.794 \\
\hline
\end{tabular}

Note: $M$-W test $=$ Mann-Whitney Rank Sum test

\subsubsection{Organic matter}

Between zones (I) and (II) organic matter in SL soil indicates a decrease in zone (II) which is greater in treatment with $\mathrm{T}$ and $\mathrm{W}(20 \mathrm{~cm}$ depth) (statistically significant ( $p=0.003$ ) t-test: $p<0.05$ ) (see Tables 8 and 9). On the other hand there were not observed any significant changes in organic matter for LS soil. Hidri et al. (2013), Belaid et al. (2012), and Mollahoseini (2013) observed that the organic matter increase is greater on topsoil, depending on the quantity of wastewater

Table 9. t-test analysis between zones (I) and (II) for SL and LS soils at $20 \mathrm{~cm}$ depth

\begin{tabular}{|c|c|c|c|}
\hline \multirow{2}{*}{ Parameters } & \multicolumn{3}{|c|}{ Test: $t$-test $p<0.05$} \\
\hline & Depth $20 \mathrm{~cm}$ & SL soil & LS soil \\
\hline \multirow{3}{*}{ Organic matter \% } & W (I)-(II) & $\begin{array}{c}1.000 \text { normality failed } \mathrm{M}-\mathrm{W} \text { test } \mathrm{p}= \\
1.000\end{array}$ & 0.233 \\
\hline & $\mathrm{T}(\mathrm{I})-(\mathrm{II})$ & 0.003 (statistically significant) & 0.291 \\
\hline & $U(I)-(I I)$ & 0.358 & 0.223 \\
\hline \multirow{3}{*}{ total $\mathrm{N} \%$} & W (I)-(II) & 0.335 & $\begin{array}{c}0.305 \text { equal variance failed } M-W \text { test } p= \\
0.400\end{array}$ \\
\hline & $T(I)-(I I)$ & 0.741 & 1.000 \\
\hline & $U(I)-(I I)$ & 0.121 & 0.044 (statistically significant) \\
\hline \multirow{3}{*}{$\mathrm{NO}_{3}-\mathrm{N} \mu \mathrm{g} / \mathrm{g}$} & W (I)-(II) & 0.294 & 0.266 \\
\hline & $\mathrm{T}(\mathrm{I})-(\mathrm{II})$ & 0.723 & 0.375 \\
\hline & $U(I)-(I I)$ & 0.783 & $\begin{array}{l}0.023 \text { equal variance failed } \mathrm{M}-\mathrm{W} \text { test } \mathrm{p}= \\
0.200\end{array}$ \\
\hline \multirow{3}{*}{$\mathrm{NH}_{4}{ }^{+}-\mathrm{N} \mu \mathrm{g} / \mathrm{g}$} & W (I)-(II) & 0.771 & 0.219 \\
\hline & $\mathrm{T}(\mathrm{I})-(\mathrm{II})$ & 0.150 & 0.784 \\
\hline & $U(I)-(I I)$ & 0.898 & 0.046 (statistically significant) \\
\hline
\end{tabular}

Note: $M-W$ test $=$ Mann-Whitney Rank Sum test

\subsubsection{Total nitrogen}

Between zones (I) and (II) total N\% showed no change in SL soil. Statistically significant differences $(p<0.05)$ were observed in LS soil with an increase greater in the upper zone (I) with $U$ wastewater $(20 \mathrm{~cm}$ depth) (see Tables 8 and 9). Majed (1999) observed that total $\mathrm{N} \%$ was not significantly affected, but according to Xua et al. (2010) and Rusan et al. (2007) total $\mathrm{N} \%$ increased in the upper soil zone up to $10 \mathrm{~cm}$ after 3,8 , and 20 years with treated wastewater irrigation. irrigation, whereas Munir et al. (2003) found that such an increase is particularly on calcareous soils, and Kiziloglou (2008) observed that organic matter \%, is greater in the upper soil layer $(0-30 \mathrm{~cm})$. A positive impact was observed in soil organic matter \% after application of treated wastewater and that is due to the fact that wastewater is rich in organic matter and in macro and micronutrients. (Gupta et al., 1998; Rusan et al., 2007). 
the added wastewater in a deeper soil layer $(60-90 \mathrm{~cm})$ while in canopy and intercanopy soil nitrates concentration $\left(\mathrm{NO}_{3}{ }^{-}\right)$were lower below a depth of $20 \mathrm{~cm}$, which was proved by the fact that at the lower depth there was no leaching in $\left(\mathrm{NO}_{3}{ }^{-}\right)$(Adhikari et al., 2014). Nitrates content is much more variable than ammonia but consistently higher in irrigated soils. Besides that, organic carbon content (SOC) decreased by depth in an irrigated soil with wastewater (Belaid et al., 2012).

\subsubsection{Ammonium}

Between zones (I) and (II) Ammonium shows a slight decrease in zone (II) for both SL and LS soils and both depths (not statistically significant) (see Tables 8 and 9). Generally, the extractable $\mathrm{NH}_{4}{ }^{+}$content remains at low levels and increases by depth in significantly higher percentage in soil irrigated with wastewater (Belaid, et al., 2012)

\section{Conclusions}

At the end of the irrigation period with $U$ untreated and $T$ treated wastewater, total $\mathrm{N} \%$, nitrates and ammonium showed an increase in SL and LS soils. Statistically significant differences $(p<0.05)$ in total N\% only in LS soil were observed. Organic matter \% did not change in SL soil but it was increased in LS soil $(p<0.05)$. The above parameters were examined in zones (I) and (II) for depths of 10 and $20 \mathrm{~cm}$. After statistical analysis $(p<0.05)$ the following differences were observed: Organic matter \% was increased in SL soil in zone (I) (irrigation with treated wastewater - $20 \mathrm{~cm}$ depth). Total N\% was increased in zone (I) and nitrates and ammonium were increased in zone (II) (irrigation with untreated wastewater-20 cm depth) in LS soil. It can be concluded that wastewater use for irrigation may lead to an increase in organic matter \% and total $\mathrm{N} \%$. Especially for Loamy Sand soils, the untreated wastewater use could enrich soil with the above nutrients. Therefore, irrigation with wastewater could offer elements in soils (especially poor ones), which will improve the soil properties and upgrade it for agricultural use in turn.

\section{References}

Abegunrin T.P., Awe G.O., Idowu D.O., Adejumobi M.A. (2016), Impact of wastewater irrigation on soil physico-chemical properties, growth and water use pattern of two indigenous vegetables in southwest Nigeria. Catena, 139, 167-178.

Adhikari P., Manoj K., Shukla J., Mexal G. and Daniel D. (2014), Irrigation with Treated Wastewater: Quantification of Changes in Soil Physical and Chemical Properties. Irrigation \& Drainage Systems Engineering, 3, 117, DOI: 10.4172/21689768.1000117.

Allen R.G., Pereira L.S., Raes D., Smith M. (1998), Crop evapotranspiration - Guidelines for computing crop water requirements. FAO irrigation and drainage, paper 56, FAO, Rome.

Alrajhi A., Beecham S., Nanthi S.B. and Hassanli A. (2015), Evaluation of soil chemical properties irrigated with recycled wastewater under partial root-zone drying irrigation for sustainable tomato production. Agricultural Water Management, 161, 127-135.
Andreadakis A., Galavaki E., Mamais D,. Tzimas A. (2003), Wastewater reuse criteria in Greece. Global Nest: The International journal. 5, (1), 9-14.

Angin I., Yaganoglu A.V. and Turan M. (2005), Effects of LongTerm Wastewater Irrigation on Soil Properties. Journal of Sustainable Agriculture, 26 (3), 31-42.

Bali M., Guedari M. and Bouckinam R. (2011), Removal of contaminants and pathogens from secondary effluents using intermittent sand filters. Water Science and Technology, 64, 2038-2043.

Bedbadis S., Rouina B., Boukhris M., and Ferrara G. (2014), Effect of irrigation with treated wastewater on soil chemical properties and infiltration rate. Journal of Environmental Management, 133, 45-50

Belaid N., Neel C., Kallel M., Ayoub T., Ayadi A. and Baudu M. (2010), Effects of treated wastewater irrigation on soil salinity and sodicity in Sfax (Tunisia): A case study. Revue des Sciences de l'Eau, 23 (2), 133-146.

Belaid N., Neel C., Lenain J.F., Buzier R., Kallel M., Ayoub T., Ayadi A., M. Baudu (2012), Assessment of metal accumulation in calcareous soil and forage crops subjected to long-term irrigation using treated wastewater: Case of $\mathrm{EI}$ Hajeb-Sfax, Tunisia. Agriculture, Ecosystems and Environment, 158, 83-93

Bernala A.D., Ramosa S.M.C., Tapiaa N.T., Portugalb V.O., Hernandezc J.T.F., \& Dendoovena L. (2006), Effects of tanneries wastewater on chemical and biological soil characteristics. Applied Soil Ecology, 33, 269-277.

Bouyoukos G.H. (1951), Recalibration of the Hydrometer Method for Making Mechanical Analysis of Soils. Agriculture journal, 43, 434-438.

Chen H.M., Zheng C.R., Tu C., Zhu Y.G. (1999), Heavy metal pollution in soils in China status and counter measures. Royal Swedish Academy of Sciences, 28,130-134

Cooper J.A., Loomis G.W., Kalen D.V., AmadorjA. (2015), Evaluation of water quality functions of conventional and advanced soil-based onsite wastewater treatment systems. Journal of Environmental Quality, 44(3), 953-962. doi: 10.2134/jeq2014.06.0277.

Duhrkoop A., Akap P.A., Aras S., Kahraman D., Muchiri E., Hensel O. (2014), "Bridging the gap between increasing knowledge and decreasing resources" Subsurface Irrigation as a Promising Approach to Reduce Pathogenic Impact When Using Wastewater. Tropentag, September 17-19, Prague, Czech Republic.

Fonseca A.F., Melfi A.J. and Montes C.R. (2005a), Maize growth and changes in soil fertility after irrigation with treated sewage effluent. I. Plant dry matter yield and soil nitrogen and phosphorus availability. Communications in Soil Science and Plant Analysis, 36, 1965-1981.

Forslund A., Ensink J.H.J., Battilani A., Kljujev I., Golae S., Raicevic V., Jovanovic Z., Stikic R., Sandei L., Fletcher T., Dalsgaard A. (2010), Fecal contamination and hygiene aspect associated with the use of treated wastewater and canal water for irrigation of potatoes (Solanum tuberosum). Agricultural Water Management, 98(3), 440-450.

Friedel J.K., Langer T., Siebe C. and Stahr K. (2000), Effects of long-term waste water irrigation on soil organic matter, soil microbial biomass and its activities in central Mexico . Biology \& Fertility Soils, 31,414-421. 
Fuentes E.R., Constantino C.L., Silva E.E. and Dendooven L. (2002), Characteristics, and carbon and nitrogen dynamics in soil irrigated with wastewater for different lengths of time. Bioresource Technology, 85, 179-187.

Galavi M., Abbas J., Ramroodi M., Mousavi S.R., and Galavi H. (2010), Effects of Treated Municipal Wastewater on Soil Chemical Properties and Heavy Metal Uptake by Sorghum (Sorghum Bicolor L.). Journal of Agricultural Science, 2, (3)

Ghanbari A., Abedikoupai J. and Tai Semiromi J. (2007), Effect of municipal wastewater irrigation on yield and quality of wheat and some soil properties in sistan zone. Journal of Science \& Technology. Agricultural and Natural Recourse, 10, 59-74.

Guo G.X., Deng H., Qiao M., Yao H.Y. and Zuu Y.G. (2013), Effect of long term wastewater irrigation on potential denitrification and denitrifying communities in soils at the watershed scale. Environmental Science \& Technology, 47 (7), 3105-3113.

Herpin U., Gloaguen T.V., Fonseca A.F., Montes C.R., Mendonca F.C., Piveli R.P., Breulmann G., Forti M.C. and Et Melfi A.J. (2007), Chemical effects on the soil-plant system in a secondary treated wastewater irrigated coffee plantation. A pilot field study in Brazil. Agriculture Water Management, 89, 105-115.

Hidri Y., Fourti O., Jedidi N. and Hassen A. (2013), Effects of ten years treated wastewater drip irrigation on soil microbiological properties under Mediterranean conditions African Journal of Biotechnology, 12 (39), 5761-5770.

Jiajie H., Doughertyb M., Arriagac F.J. and Abdelaziz H.A. (2013), Impact of a real-time controlled wastewater subsurface drip disposal system on the selected chemical properties of a vertisol. Environmental Technology, 34 (10), 1341-1347.

Kalavrouziotis I., Koukoulakis P., Papaioannou D., and Mehra A., 2018, pH and organic matter impact on the indices of soil metal load assessment under wastewater and biosolid reuse. Journal of Chemical Technology and Biotechnology, 93 (11), 3244-3253.

Kiziloglu F.M., M. Turan M., Sahin U., Kuslu Y., Dursun A. (2008), Effects of untreated and treated wastewater irrigation on some chemical properties of cauliflower (Brassica olerecea L. var. botrytis) and red cabbage (Brassica olerecea L. var. rubra) grown on calcareous soil in Turkey. Agricultural water management, 95, 716-724.

Lado M., Zapateira A., Azenkot A., Assouline S., Ravina I., Erner Y., Fine P., Dasberg S. and Ben-Hur M. (2012), Changes in Chemical Properties of Semiarid Soils under Long-Term Secondary Treated Wastewater Irrigation. Soil Sci. Soc. Am. J., 76, 1358-1369.

Lance J.C. and Whisler F.D. (1972), Nitrogen Balance in Soil Columns Intermittently Flooded with Secondary Sewage Effluent. Journal of Environmental Quality, 1 (2), 180-186.

Lian J., Luo Z. and Jin M. (2013), Transport and fate of bacteria in SAT system recharged with recycling water. International Biodeterioration and Biodegradation, 76, 98-101.

Magesan G.N. (2001), Changes in soil physical properties after irrigation of two forested soils with municipal wastewater. New Zealand forest Research Institute. Issue 2, 762-767.

Magesan G.N., Mclay C.D.A. and Lal V.V. (1998), Nitrate leaching from a freely-draining volcanic soil irrigated with municipal sewage effluent in New Zealand. Agriculture Ecosystems \& Environment, 70, 181-187.
Majed P. and Danesh S. (1999), Effects of irrigation with treated wastewater on Some Chemical Soil Properties in Parkandabad. Irrigation Department, College of Agriculture, Ferdowsi University of Mashhad, Iran.

Mohammad M.J., and Mazahreh N. (2003), Changes in soil fertility parameters in response to irrigation of forage crops with secondary treated wastewater. Communication Soil Science Plant Analysis, 34, 1281-1294.

Mohammad M.J., Hinnawi S. and Rousan L. (2007), Long term effect of wastewater irrigation of forage crops on soil and plant quality parameters. Desalination, 215, 143-152.

Mollahoseini H. (2013), Long term effects of municipal wastewater irrigation on some properties of a semiarid region soil of Iran. International journal of Agronomy \& Plant Production, 4 (5), 1023-1028.

Monnett G.T., Reneau R.B. and Hagedorn C. (1996), Evaluation of spray irrigation for on-site wastewater treatment and disposal on marginal soils. Water Environmental Research, 68, 11-18.

Munir J.M., Mazahreh N. (2003), Changes in soil fertility parameters in response to irrigation of forage crops with secondary treated wastewater, Communications in soil sciences and plant analysis 34 (9-10), 1281-1294.

Nelson D.W. and Sommers L.E. (1982), Total Carbon, organic carbon and organic matter. In A.L. Page et al. (ed). Methods of soil Analysis, Part 2, Chemical and Microbiological Properties, $2^{\text {nd }}$ edition, Agronomy Monograph 9. ASA and SSSA, Madison, WI, 561-580.

Nola M., Nijine T., Kemka N. (...), Messouli M., and Boutin C. (2006), Retention of staphylococci and total coliforms during wastewater percolation through equatorial soil in Central Africa. The role of the soil column near soil surface and that closely above groundwater table. Water, Air and Pollution, 171 (1-4), 253-271.

Qian Y.L. and Mecham B. (2005), Long-Term Effects of Recycled Wastewater Irrigation on Soil Chemical Properties on Golf Course Fairways. Agronomy Journal, 97, 717-721.

Rusan M.J.M., Hinnawi S. and Rousan L. (2007), Long term effect of wastewater irrigation of forage crops on soil and plant quality parameters. Desalination, 215, 143-152.

SL Press (2019), UN: Water will be a worldwide problem in the coming years, https://slpress.gr/, e-newspaper 3/19/2019 (in Greek).

Tyler E.J., Laak R., McCoy E. and Sandhu S.S. (1977), The soil as a treatment system. Paper presented at the second National Home sewage Treatment Symposium. Chicago, Illinois, USA.

Wagner W., Carlos A., Dantas J.N., Antunes L. and Wellington J. (2006), Treated Wastewater and Nitrogen: Effects on the Chemical Properties of the Soil. American society of Agricultural and biological engineers. ASABE Annual International Meeting Portland, Oregon, 9 - 12 July, 2006.

WHO, 2018, Water sanitation hygiene strategy 2018-2025

Xua J., Laosheng W., Changb A.C. and Zhanga Y. (2010), Impact of long-term reclaimed wastewater irrigation on agricultural soils: A preliminary assessment. Journal of Hazardous Materials, 183, 780-786

Yadav B., Goyal R.K., Sharma S.K., Dubey P.S. and Minhas R.K. (2002). Post-irrigation impact of domestic sewage effluent on composition of soils, crops and groundwater. A case study. Environment International, 28, 481- 486. 
Zhang C., Zhongyi L., Weiwei Y., Liping P., Minghua G. and Dokyoung L. (2013), Assessment of Metals Pollution on Agricultural Soil Surrounding a Lead-Zinc Mining Area in the Karst Region of Guangxi, China. Bulletin of Environmental Contamination and Toxicology, 90, 736-741.

Zhang Y.L., Dai J.L., Wang R.Q. and Zhang J. (2008), Effects of long-term sewage irrigation on agricultural soil microbial structural and functional characterizations in Shandong, China. European Journal of Soil Biology, 44, 84-91. 